\title{
The Use of Project-Based Learning Using Visual Art to Increase Students' Interest and Creativity
}

\author{
A U Prianji \\ Surabaya, Indonesia
}

\author{
W Widodo \\ Surabaya, Indonesia
}

\author{
T Kirana \\ Surabaya, Indonesia
}

\begin{abstract}
The aim of this study was to produce a valid, practical, and effective learning material for project-based learning using visual art to increase the elementary school students' interest and creativity. This research was conducted through three stages of 4-D model contrived by Thiagarajan et al. The results showed that in terms of the validity, effectiveness, and practicality, the learning materials developed were valid and could be implemented in the classroom. Furthermore, the students' interest improved after the implementation of the project-based learning model using visual art which resulted score 3.42 or $85.50 \%$.
\end{abstract}

\section{Keywords-Project-Based Learning; Interest and Creativity}

\section{INTRODUCTION}

Basically, science in elementary schools aims at having students organize their knowledge and ideas about the natural surroundings gained from the experience through a series of scientific processes between investigation, compilation, and presentation of ideas $[10,11]$. In today's digital era, science learning requires students to be more creative and interesting as it uses 4C's skill (21st Century skills). Based on the Law No. 22 of 2016 the learning process in the educational unit is held interactively and inspirationally and, at the same time, provides sufficient space for initiation, creativity, and independence according to the talents, interests, physical and psychological development of the learners [13]. From the results of the interviews and observations, a learning is considered less meaningful if it does not use the strategy / learning model which is in line with the material being taught. The observation results showed that teachers, in conducting a teaching-learning process, often employed the same method of all subjects so that the $4 \mathrm{c}$ skill was not involved. The result of observation showed that students' creative thinking ability in the learning activities was mainly low. There were only $20 \%$ of students could think fluently, $30 \%$ of them could think flexibly, $40 \%$ had original thinking ability, and $30 \%$ of them could elaborate their thinking. It was proven that the lack of variation in learning led to the students' low creativity and low interest in science.
A research on project-based learning that has been conducted by Joao Alberto Arantes do Amaral, Paulo Goncalves, Aurelio Hess (2015), showed that the project skills can improve the students' learning and managerial skills. Ciftci, Sabahattin, and Baykan (2013) conclude that, although there are significant gender differences in environmental behavior, there is no negative effect on the project learning. The results of research conducted by Lata Tomjenovic (2015) showed that the method of learning combined with visual arts activities resulted a significant increase in the students' learning outcomes. They were more active, creative, as well as having affective experience and motor activity increase. Furthermore, Slahova, Alexandra, et al in their research found that there was a linkage in the development of the creative imagination of elementary school students and creative activities when describing visual art portraits [8].

Based on the results of the existing research, the projectbased learning using visual art was then developed to increase the students' interest and creativity. Th study used a projectbased approach combined with visual arts activities to increase elementary school students' interest and creativity. The project activities begin with fundamental questions, planning, project implementation rules, scheduled activities, monitoring student project progress, assessing students' work, and the process is ended with evaluating student experience. In the project activities carried out, visual art activities were combined so that the students were more interested in the teaching and learning activities. The study was conducted using three stages of 4-D model proposed by Thiagarajan et al. model covering defining, designing and developing stages. The implementation of visual arts in the project-based learning model resulted in the improvement of interest and creativity of students in science lesson. The students become more interested and creative in the teaching and learning process. Furthermore, the boredom in learning activities was slowly replaced by the interesting activities of students in every process of teaching and learning. 


\section{METHOD}

This study focused on the software development model learning project-based learning using visual art that referred to a 4-D model. However, this study only used 3D model with the qualitative design which aims at describing or revealing in detail about the process and learning outcomes related to the elementary students' interest and creativity of learning science with the light material property.

The subjects in this study were the students of grade IV of elementary school with 20 students in total for the material of nature of light. The characteristics of the students as the subject of this study were the students who had low interest in science and ability to think creatively. The teaching-learning process tended to be teacher-centered so that students' creativity in thinking skills were poorly trained resulting in the low interests in doing the activities.

The analytical techniques applied in this study were descriptive quantitative and qualitative, which analyzed the students' learning activities and interest in learning and creativity of the students. The analysis used presentation technique with the following formula:

$\mathrm{P}=\frac{\sum K}{\sum \mathrm{N}} \mathrm{x} 100 \%$

The analysis of student learning activities was obtained through the observation sheet filled by the observer during the learning activities. The student learning activity sheet consisted of nine indicators that must be observed by the observer by giving a score of 1 to 4 . Meanwhile, the analysis of data on the students' interest obtained was done using questionnaires which consisted of 20 questions with four indicators of interest as follows: feeling good about teaching science, interest towards science subjects, attention to the teacher, and the spirit of students in participating in science lessons [14]. Students' interest questionnaires in learning were filled by the students at the end of the learning activity by cross-marking ( $\mathrm{x}$ ) with two optional choices, yes or no. The analysis on the students' creativity was taken using the creativity test in the form of pretest and posttest. The aspects represented the creative thinking abilities were originality, fluency, flexibility, and elaboration.

Furthermore, to determine the level of sensitivity, pre-test and post-test on students' creativity tests performed using the $\mathrm{N}$-gain was analyzed as follows.

$N$-gain $=\frac{\text { skorposttest }- \text { skorpretest }}{\text { skormaximal-skorpretest }}$

(Djamarah, 2010)

\section{RESULTS AND DISCUSSION}

\subsection{Learning activity}

The results of analysis in student learning activities could be seen from the questionnaire that had been filled by the observers. In the learning model of project-based using visual art, it was obtained some activities including paying attention the teacher which got the highest average score of $19.2 \%$, followed by answering questions given by the teachers which got $12.8 \%$, doing worksheets provided by the teacher which got $14.1 \%$, cooperating with friends in the group with $11.9 \%$, discussing problems encountered in groups which got $11.6 \%$, taking opinions among friends in groups with percentage $10.8 \%$, making decisions on all the correct answers with percentage $5.1 \%$, presenting answers in front of class with percentage $4.8 \%$, and responding to friends' answers which got $9.7 \%$. The results are shown in Fig 1. below:

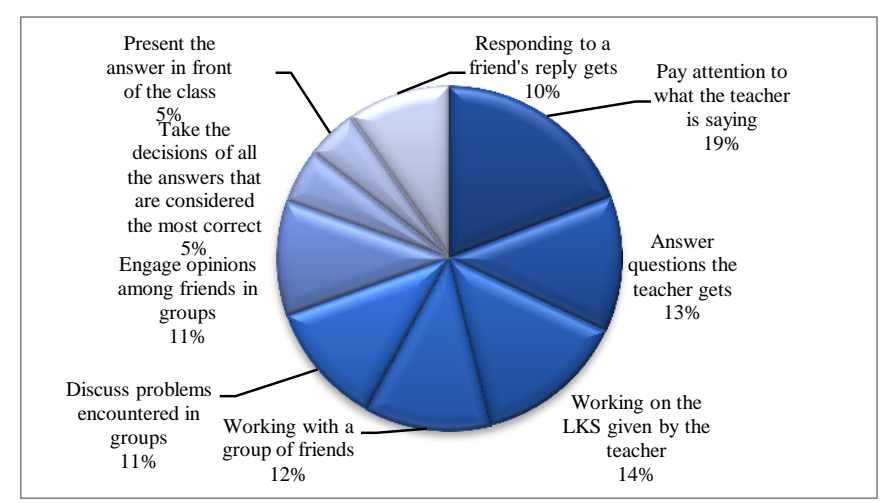

Fig. 1. Results of Student Learning Activity Analysis

Based on the results of the analysis on student learning activities, it could be concluded that the teaching and learning activities were more active as marked with the number of students who answered every question from the teacher. In addition, the students were enthusiastic in working on any given activities sheets. They also cooperated better with the other students in every learning activities. In line with the opinion of Ahmadi, a group learning is an activity conducted by two or more people to discuss a subject matter to be solved [15]. The process of learning through Project-based using visual art was done in groups and was proven to be successful in improving the students' learning activities.

\subsection{Interest}

The result of data analysis on the students' interest in learning analysis are presented in the following table.

TABLE I. The Result of StUdents' INTEREST ANALYSIS

\begin{tabular}{|l|l|l|l|l|l|}
\hline No. & Name & $\begin{array}{l}\text { Total } \\
\text { Aspect } \\
\text { Interest }\end{array}$ & $\begin{array}{l}\text { Total } \\
\text { Aspect } \\
\text { Observa } \\
\text { tion }\end{array}$ & $\begin{array}{l}\text { Pro- } \\
\text { sentan- } \\
\text { ce }\end{array}$ & Criteria \\
\hline $\mathbf{1}$ & AJR & 19 & 20 & $95 \%$ & Very interested \\
\hline $\mathbf{2}$ & AHY & 17 & 20 & $85 \%$ & Very interested \\
\hline $\mathbf{3}$ & ARP & 18 & 20 & $90 \%$ & Very interested \\
\hline $\mathbf{4}$ & AS & 18 & 20 & $90 \%$ & Very interested \\
\hline $\mathbf{5}$ & AO & 16 & 20 & $80 \%$ & Very interested \\
\hline $\mathbf{6}$ & DF & 16 & 20 & $80 \%$ & Very interested \\
\hline $\mathbf{7}$ & ES & 16 & 20 & $80 \%$ & Very interested \\
\hline $\mathbf{8}$ & FA & 18 & 20 & $90 \%$ & Very interested \\
\hline $\mathbf{9}$ & FS & 16 & 20 & $80 \%$ & Very interested \\
\hline $\mathbf{1 0}$ & GB & 20 & 20 & $100 \%$ & Very interested \\
\hline $\mathbf{1 1}$ & MRC & 19 & 20 & $95 \%$ & Very interested \\
\hline
\end{tabular}




\begin{tabular}{|l|l|l|l|l|l|}
\hline No. & Name & $\begin{array}{l}\text { Total } \\
\text { Aspect } \\
\text { Interest }\end{array}$ & $\begin{array}{l}\text { Total } \\
\text { Aspect } \\
\text { Observa } \\
\text { tion }\end{array}$ & $\begin{array}{l}\text { Pro- } \\
\text { sentan- } \\
\text { ce }\end{array}$ & Criteria \\
\hline $\mathbf{1 2}$ & MN & 12 & 20 & $60 \%$ & Have a good interest \\
\hline $\mathbf{1 3}$ & MM & 20 & 20 & $100 \%$ & Very interested \\
\hline $\mathbf{1 4}$ & MRK & 17 & 20 & $85 \%$ & Very interested \\
\hline $\mathbf{1 5}$ & NRR & 16 & 20 & $80 \%$ & Very interested \\
\hline $\mathbf{1 6}$ & RAF & 17 & 20 & $85 \%$ & Very interested \\
\hline $\mathbf{1 7}$ & RWA & 20 & 20 & $100 \%$ & Very interested \\
\hline $\mathbf{1 8}$ & RDS & 16 & 20 & $80 \%$ & Very interested \\
\hline $\mathbf{1 9}$ & WL & 18 & 20 & $90 \%$ & Very interested \\
\hline $\mathbf{2 0}$ & ZM & 13 & 20 & $65 \%$ & Have a good interest \\
\hline \multicolumn{2}{|l}{ Total } & 342 & 400 & $85.5 \%$ & Very interested \\
\hline
\end{tabular}

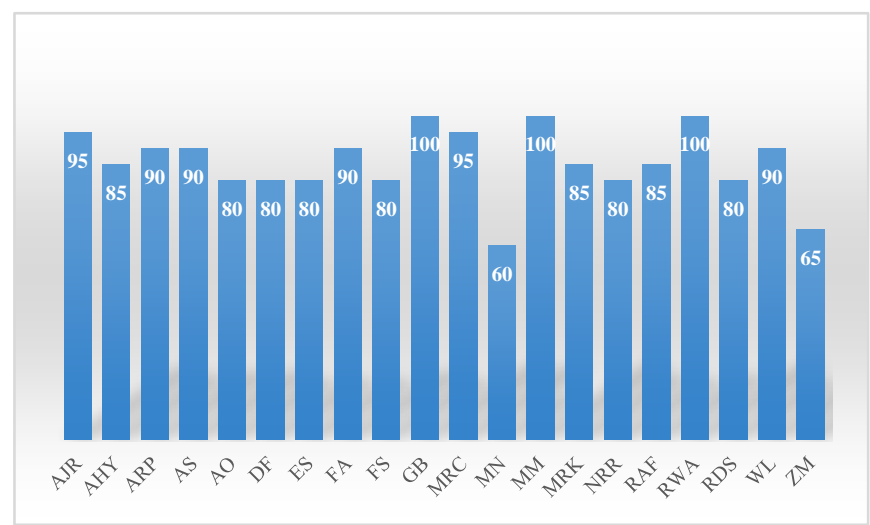

Fig. 2. The Result of students' interest

The students, along the process of teaching and learning, filled the questionnaires given. The questionnaire consisted of 20 items with 15 positive statements of yes answer and 5 negative statements with no answer. The result of the students' interest analysis got the average score of 3.42 or $85.5 \%$ with very interested criteria. The students had a positive interest towards the project-based learning models using visual art developed. Crow \&Crow [3] state that interest relates to the style of motion that encourages a person to deal with people, objects, activities, experiences that are stimulated by the activity itself. Therefore, the high interest will have an impact on the high creativity as well.

\subsection{Creativity}

The data on the students' creative thinking ability are presented in the following table.
TABLE II. THE RESULT OF STUDENTS' CREATIVITY ANALYSIS

\begin{tabular}{|c|c|c|c|}
\hline Aspects & Pretest & Posttest & N-Gain \\
\hline Fluency & 68,8 & 96,3 & 0,88 \\
\hline Flexibility & 65,0 & 90,0 & 0,71 \\
\hline Originality & 67,5 & 91,3 & 0,73 \\
\hline Elaboration & 58,8 & 88,8 & 0,73 \\
\hline
\end{tabular}



Fig. 3. The Result of Students' Creative Thinking Ability Analysis

The results of the analysis showed that creative thinking ability of the students scored by $\mathrm{N}$-gain showed that their ability to think fluently was at 0.88 with high criteria, to think flexibly get score 0.71 with the high criteria, to think originally got score of 0.73 with high criteria, and to think with elaboration got $N$-gain score of 0.73 with high criteria. Based on the existing results, it could be concluded that there was an increase in students' creative thinking ability in the learning activities undertaken. The students became more creative than the previous condition. Munandar states that creativity comes from inside and outside the individuals themselves. Furthermore, an environmental condition that can nurture the creative power of the individual the environment where students learn (school) was needed [6].

\subsection{Learning outcomes}

The data on the students' learning outcomes can be seen in following table.

TABLE III. THE RESUlt OF PRE-TEST AND POST-TEST AsSESSMENT OF STUDENTS' LEARNING OUTCOMES

\begin{tabular}{|l|c|c|c|c|c|c|}
\hline \multirow{2}{*}{ No } & \multirow{2}{*}{ Name } & \multicolumn{4}{|c|}{ Result } & \multirow{2}{*}{ N-gain } \\
\cline { 3 - 6 } & & \multicolumn{2}{|c|}{ Value } & \multicolumn{2}{c|}{ Completeness } & \multirow{2}{*}{} \\
\cline { 3 - 6 } & & Pretest & Posttest & Pretest & Posttest & \\
\hline $\mathbf{1}$ & AJR & 40 & 80 & TT & T & 0.67 \\
\hline $\mathbf{2}$ & AHY & 43 & 87 & TT & T & 0.77 \\
\hline $\mathbf{3}$ & ARP & 40 & 83 & TT & T & 0.72 \\
\hline $\mathbf{4}$ & AS & 33 & 80 & TT & T & 0.70 \\
\hline $\mathbf{5}$ & AO & 43 & 90 & TT & T & 0.83 \\
\hline $\mathbf{6}$ & DF & 47 & 80 & TT & T & 0.62 \\
\hline
\end{tabular}




\begin{tabular}{|l|c|c|c|c|c|c|}
\hline \multirow{2}{*}{ No } & \multirow{2}{*}{ Name } & \multicolumn{4}{|c|}{ Result } & \multirow{2}{*}{ N-gain } \\
\cline { 3 - 6 } & & \multicolumn{2}{|c|}{ Value } & \multicolumn{2}{c|}{ Completeness } & \multirow{2}{*}{} \\
\cline { 3 - 6 } & & Pretest & Posttest & Pretest & Posttest & \\
\hline $\mathbf{7}$ & ES & 30 & 73 & TT & T & 0.61 \\
\hline $\mathbf{8}$ & FA & 37 & 87 & TT & T & 0.79 \\
\hline $\mathbf{9}$ & FF & 43 & 83 & TT & T & 0.70 \\
\hline $\mathbf{1 0}$ & GB & 67 & 98 & TT & T & 0.94 \\
\hline $\mathbf{1 1}$ & MRC. & 57 & 86 & TT & T & 0.67 \\
\hline $\mathbf{1 2}$ & MN & 63 & 90 & TT & T & 0.73 \\
\hline $\mathbf{1 3}$ & MM & 63 & 98 & TT & T & 0.95 \\
\hline $\mathbf{1 4}$ & MRK & 60 & 83 & TT & T & 0.58 \\
\hline $\mathbf{1 5}$ & NRR & 50 & 80 & TT & T & 0.60 \\
\hline $\mathbf{1 6}$ & RAF & 50 & 90 & TT & T & 0.80 \\
\hline $\mathbf{1 7}$ & RWA & 33 & 83 & TT & T & 0.75 \\
\hline $\mathbf{1 8}$ & RDS & 43 & 83 & TT & T & 0.70 \\
\hline $\mathbf{1 9}$ & WL & 57 & 87 & TT & T & 0.70 \\
\hline $\mathbf{2 0}$ & ZM & 53 & 80 & TT & T & 0.57 \\
\hline \multicolumn{2}{|c|}{ Total } & 952 & 1701 & TT & T & 0.72 \\
\hline
\end{tabular}

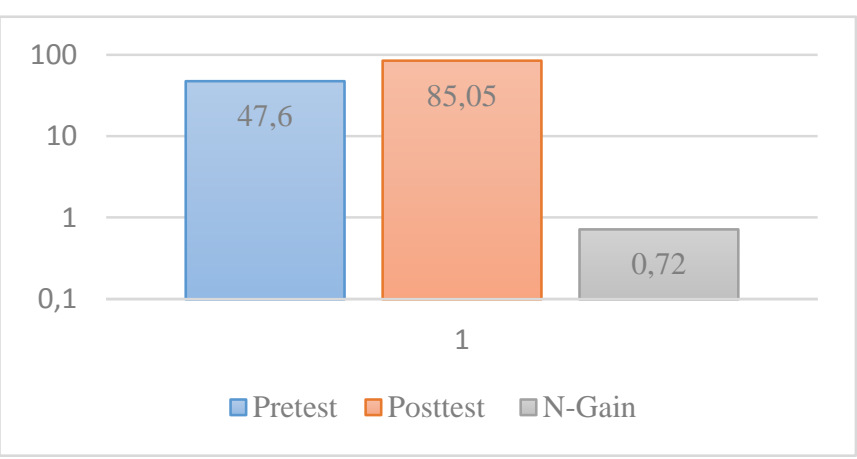

Fig. 4. The Result of $P H B$

The students' interest and creativity toward the learning process were increased and it had made a positive impact on their learning outcomes. It was proven that the students' learning outcomes increased after applying the learning activity through project-based learning model using visual art. In the implementation of pretest and posttest that had been done by students, the result showed that the learning outcomes (PHB), increase. It could be seen from the average $\mathrm{N}$-gain score the of pretest and posttest score that the PHB got score 0,72 with high criterion. In line with Rizema (2013), good pedagogy engages students to do experiment on their own, try to manipulate signs and symbols, try to ask questions, find their own answers, and compare their findings with other students. In addition, Brunner [7] states that learning is a process whereby a student is assisted by a teacher or other person who has higher ability to solve a particular problem which thereby exceed his capacity.

\section{CONCLUSION}

In conclusion, creative thinking abilities of the students after the implementation of project-based learning using visual arts are getting better. It can be seen from the increase of students' interest in the teaching and learning process. In order to develop the ability to think creatively and to encourage the students' interests, a learning should be designed in the form of project that challenge students to be more creative, imaginative and even try to be a designer in every material being taught.

\section{REFERENCES}

[1] Buletnt, Guffor, Timur, Koparan, "The effect on the $8^{\text {th }}$ grade students attitude toward statistic of project based learning", in European journal of educational research, Vol 3 No. 2, pp 73-85, 2014

[2] Ciftci, Sabahattin, and Baykan, "Project Based Learning in Multy Grade Class"., in Eric Jurnal, Vol. 8 No. 3, pp 84-92, Feb 2013, 2013

[3] Djaali, PsikologiPendidikan. Jakarta: PT Bumi Aksara, 2008

[4] Djamarah, S. Bachri and A. Zain, Strategi Belajar Mengajar, Jakarta: Rineka Cipta, 2010

[5] Alberto J, Arantes, A Paulo, and Awake, :Creating a project-based learning emvironment to improve project manageman skill of graduate students", in Journal of problem based learning educatioan, Vol 3 No 2, pp 120-130, 2015

[6] U Munandar, Pengembangan Kreativitas Anak Berbakat, Jakarta: Rineka Cipta, 2012

[7] S Rizema, Desain Belajar Mengajar Kreatif Berbasis Sains, Yogyakarta: Diva Press, 2013

[8] Slakova, Alexandra, volonteizle, cackamaks, "Development of creative imagination of primary school from visual art”, in Journal of art, 2017

[9] T Zlata, "An interactive approach to learning and teaching visual art education", EEPS Journal, Vol 1 No 3, pp 73-93, 2015

[10] N G John, "Science in elementary schools", in American Journal of Physics, Vol. 27, p 424, 1959

[11] J H Gladstone, "Science in Elementary Schools", in Nature, Vol. 59, No. 126,1898

[12] D Moursund, Project-BasedLearning Using Information Technology, Eugene, OR: International Society for Technology in Education, 1999

[13] Menteri Pendidikan dan Kebudayaan Republik Indonesia, Peraturan Menteri Pendidikan dan Kebudayaan Republik Indonesia No. 22 Tahun 2016 tentang Standar Proses Pendidikan Dasar dan Menengah, 2016

[14] B Slameto, Faktor-Faktor yang Mempengaruhinya, Edisi Revisi, Jakarta: Rineka Cipta, 2003

[15] I El-Feghi, M A Sid-Ahmed, and M Ahmadi, "Automatic localization of craniofcial landmarks for assisted cephalometry", in Pattern Recognition, Vol. 37 Issue 3, pp 609-621, March 2004, 2004 